\title{
EFEK KEBOCORAN BEAMTUBE DAN PIPA PRIMER PENUKAR PANAS PADA SUATU MODEL REAKTOR RISET 1 MW BERBAHAN BAKAR TIPE SILINDER
}

\section{THE LEAKAGE EFFECT OF BEAMTUBE AND PRIMARY PIPE OF HEAT EXCHANGER ON A 1 MW RESEARCH REACTOR MODEL WITH CYLINDRICAL FUELS}

\author{
Reinaldy Nazar \\ Pusat Teknologi Nuklir Bahan dan Radiometri, BATAN \\ Jl. Tamansari No. 71, Bandung - 40123. \\ e-mail: reinaldynazar@batan.go.id
}

Diterima 15 Mei 2013, diterima dalam bentuk perbaikan 12 Juni 2013, disetujui 13 Juni 2013

\begin{abstract}
ABSTRAK
EFEK KEBOCORAN BEAMTUBE DAN PIPA PRIMER PENUKAR PANAS PADA SUATU MODEL REAKTOR RISET 1 MW BERBAHAN BAKAR TIPE SILINDER. Telah dilakukan analisis transien menggunakan program komputer RELAP5/Mod3.2 terhadap model reaktor riset berbahan bakar tipe silinder daya 1 MW dan diasumsikan mengalami kebocoran pada beamtube, pipa cold leg, dan pipa hot leg. Berdasarkan hasil analisis diketahui reaktor mencapai kestabilan pada daya 1 MW adalah 1650 detik setelah kekritisan. Pada kondisi stabil suhu pusat dan suhu kelongsong bahan bakar pada kanal terpanas, serta suhu air pendingin primer keluar dari kanal terkait berturut-turut adalah $529,35^{\circ} \mathrm{C}, 98,37^{\circ} \mathrm{C}, 81,27^{\circ} \mathrm{C}$. Pada 7,3 detik setelah beamtube bocor, atau 5,1 detik setelah pipa cold leg bocor, atau 6,2 detik setelah pipa hot leg bocor reaktor scram karena level air tangki telah turun $0,5 \mathrm{~m}$. Penurunan air tangki ini terhenti pada level 0,959 m ketika 97,7 detik setelah beamtube bocor, atau pada level 1,252 m ketika 76,4 detik setelah pipa cold leg bocor, atau pada level 1,252 m ketika 78,6 detik setelah pipa hot leg bocor. Pada kondisi ini suhu pusat dan suhu kelongsong bahan bakar pada kanal terpanas, serta suhu air pendingin primer keluar dari kanal terkait berturut-turut adalah $96,25^{\circ} \mathrm{C}, 89,63^{\circ} \mathrm{C}, 78,96^{\circ} \mathrm{C}$ untuk kebocoran beamtube, atau $87,1{ }^{\circ} \mathrm{C}$, $78,31^{\circ} \mathrm{C}, 69,10^{\circ} \mathrm{C}$ untuk kebocoran pipa cold leg, atau $87,32{ }^{\circ} \mathrm{C}, 78,54{ }^{\circ} \mathrm{C}, 69,43^{\circ} \mathrm{C}$ untuk kebocoran pipa hot leg. Berbeda dengan kebocoran pada pipa cold leg dan pipa hot leg, suhu-suhu tersebut pada kebocoran beamtube cenderung terus naik karena sisa panas peluruhan, dan air tangki yang tersedia tidak mampu mengambil panas tersebut secara maksimal, sehingga diperlukan sistem pendinginan teras darurat (SPTD) untuk mendinginkannya.
\end{abstract}

Katakunci : reaktor riset, daya $1 \mathrm{MW}$, beamtube, colg leg, hot leg.

\begin{abstract}
THE LEAKAGE EFFECT OF BEAMTUBE AND PRIMARY PIPE OF HEAT EXCHANGER ON A 1 MW RESEARCH REACTOR MODEL WITH CYLINDRICAL FUELS. Transient analysis has been done using a computer program RELAP5/Mod3.2 on a research reactor models with cylindrical fuels on $1 \mathrm{MW}$ power and a leak in the beamtube, cold leg and hot leg pipes. Based on the analysis, reactor achieves stability in $1 \mathrm{MW}$ power is 1650 seconds after reached criticality. In this steady state the suhue of the fuel center, the suhue of fuel cladding, the suhue of primary cooling water out of the hottest channel are $529.35^{\circ} \mathrm{C}, 98.37^{\circ} \mathrm{C}, 81.27$ ${ }^{\circ} \mathrm{C}$ respectively. At 7.3 seconds after the beamtube leaking, or 5.1 seconds after the cold leg pipes leakage, or 6.2 seconds after the hot leg pipe leakage, reactor scramed, because the tank water level fell by $0.5 \mathrm{~cm}$. The decrease of this tank water stopped at the level of $0.959 \mathrm{~m}$ when 97.7 seconds after beamtube leakage, or at the level of $1.252 \mathrm{~m}$ when 76.4 seconds after a cold leg pipe leak, or at the level of $1.252 \mathrm{~m}$ when 78.6 seconds after the leaking of hot leg pipe. In this condition the suhue of the fuel center, the suhue of fuel cladding, the suhue of primary cooling water out of the hottest channel are $96.25^{\circ} \mathrm{C}, 89.63{ }^{\circ} \mathrm{C}, 78.96{ }^{\circ} \mathrm{C}$ respectively for the beamtube leaking, or $87.1{ }^{\circ} \mathrm{C}, 78.31^{\circ} \mathrm{C}, 69.10^{\circ} \mathrm{C}$ respectively for the cold leg pipes leak, or $87.32{ }^{\circ} \mathrm{C}, 78.54^{\circ} \mathrm{C}, 69.4{ }^{\circ} \mathrm{C}$ respectively for the hot leg pipes leak. Different from cold leg pipe and hot leg pipe leak, on the leaking of beamtube the suhues are likely to rise due to residual decay heat, and the available tank water that do not able to take the heat to the maximum, so it is required emergency core cooling system (ECCS) to cool it.
\end{abstract}


Jurnal Iptek Nuklir Ganendra

Ganendra Journal of Nuclear Science and Technology

Vol. 16 No. 2 Juli 2013: 97-107

Keywords: research reactor, 1 MW power, beamtube, colg leg, hot leg.

\section{PENDAHULUAN}

D alam mengoperasikan suatu reaktor riset perlu diidentifikasi paramater-parameter yang terkait dengan keselamatan operasi reaktor guna mendapatkan nilai-nilai batas keselamatan operasi, baik dalam keadaan operasi normal maupun keadaan kecelakaan (tidak normal). Ada beberapa kategori kecelakaan yang dipostulasikan dapat terjadi pada reaktor riset ketika beroperasi, di antaranya adalah kehilangan air pendingin primer (Loss of Coolant Accident - LOCA) disebabkan sistem pipa primer pecah, beamtube terputus atau pecahnya tangki reaktor. Peristiwa ini dapat menyebabkan hilangnya air pendingin primer secara total, serta naiknya suhu bahan bakar dan air pendingin primer reaktor. Begitu juga halnya dengan model reaktor riset berbahan bakar tipe silinder yang saat ini masih banyak dioperasikan di beberapa negara Asia, Afrika, dan Amerika Selatan tidak terlepas dari kejadian LOCA tersebut. Untuk itu perlu diidentifikasi paramater-parameter yang terkait dengan keselamatan operasi reaktor guna mendapatkan nilai batas keselamatan operasi, di antaranya ketika reaktor dioperasikan pada daya terbatas $1 \mathrm{MW}$.

Guna mendapatkan nilai parameter-parameter batas keselamatan tersebut, diantaranya perlu dilakukan kegiatan eksperimen dan kajian teoritik berdasarkan aspek termohidrolik terhadap kondisi operasi reaktor tersebut. Kegiatan eksperimen dan kajian teoritik menggunakan program komputer adalah dua metode penelitian reaktor yang saling melengkapi dan sama pentingnya, dimana data-data parameter operasi reaktor yang tidak dapat diperoleh melalui kegiatan eksperimen dapat diperoleh melalui kajian teoritik dan begitu juga sebaliknya. Mengingat eksperimen kehilangan air pendingin primer (LOCA) reaktor tidak mungkin dapat dilakukan, maka dilakukan kajian teoritik menggunakan program komputer RELAP5/Mod3.2. Dalam kajian ini hanya dianalisis tiga kasus kebocoran yang terjadi secara terpisah, yaitu kebocoran pada beamtube, kebocoran pipa cold leg pada sisi primer keluaran penukar panas, dan kebocoran pipa hot leg pada sisi primer masuk penukar panas. Namun kebocoran tangki reaktor yang menyebabkan terkurasnya air tangki tidak dianalisis, karena kebolehjadian terjadinya sangat kecil.

Kegiatan yang hampir sama telah pernah dilakukan oleh para peneliti sebelumnya ${ }^{(1,2)}$, tetapi pada penelitian ini dilakukan kajian terhadap suatu bentuk modifikasi model reaktor riset yang sangat berbeda dengan penelitian sebelumnya. Teras reaktor riset yang ditinjau memiliki 107 bahan bakar dimodelkan dengan 7 kanal, dan antara kanal-kanal yang berdekatan terjadi crossflow. Model reaktor yang ditinjau mengakomodasi keberadaan sistem difuser yang mempengaruhi suhu pendingin keluar dari teras reaktor. Sedangkan sistem scram reaktor yang digunakan adalah jika level air pendingin primer di dalam tangki turun $0,5 \mathrm{~m}$ maka reaktor scram. Selain menganalisis kasus kebocoran yang terjadi pada beamtube serta pipa cold leg di sisi primer keluaran alat penukar panas, juga dianalisis kasus kebocoran terjadi pada pipa hot leg di sisi primer masukan alat penukar panas, sehingga diharapkan hasil penelitian ini dapat melengkapi penelitian-penelitian sebelumnya dalam upaya mengumpulkan data-data nilai batas keselamatan operasi untuk reaktor riset berbahan bakar tipe silinder yang masih banyak dioperasikan di dunia saat ini.

\section{METODOLOGI}

\section{Deskripsi Model Reaktor Riset Berbahan Bakar Tipe Silider yang Dikaji}

Dalam melakukan kajian ini, diambil suatu model reaktor riset berbahan bakar tipe silinder (Gambar 1), yang memiliki 121 lubang kisi (grid) untuk menyusun bahan bakar di dalam teras reaktor. Adapun spesifikasi reaktor riset yang dikaji terdiri dari: tangki reaktor, sistem pendingin primer dan sistem pendingin sekunder. Tangki reaktor berdiameter dalam 1,981 meter, tinggi 7,85 m dan diisi dengan air murni sampai ketinggian 7,652 $\mathrm{m}$. Sistem pendingin primer terdiri dari pompa sentrifugal untuk mengalirkan air pendingin keluar dan masuk tangki reaktor, alat penukar panas tipe pelat untuk memindahkan panas dari sistem primer ke sistem sekunder serta beberapa katup untuk mengatur aliran. Sistem pendingin sekunder terdiri dari menara pendingin, pompa sentrifugal untuk mengalirkan air pendingin keluar dan masuk menara pendingin, dan katup untuk mengatur aliran. 
Pipa primer yang digunakan berukuran 6 inci, dimana posisi ujung pipa primer untuk pendingin masuk ke tangki reaktor adalah 1, 252 dari dasar tangki atau sejajar dengan permukaan teras, dan posisi ujung pipa primer untuk pendingin keluar dari tangki reaktor berada $0,70 \mathrm{~m}$ di bawah permukaan tangki. Beamtube sebagai pipa berkas penyalur partikel aktif ke luar tangki, merupakan pipa ukuran 6 inci penghubung dinding teras dengan luar tangki melalui bypass teras.

Reaktor yang ditinjau memiliki sistem difuser yang terdiri dari pompa, sistem pemipaan, katup-katup, dan nozzle yang ditempatkan di atas cerobong teras reaktor. Air pendingin primer yang keluar dari nozzle difuser disamping akan menurunkan suhu air pendingin primer yang keluar dari teras reaktor, cerobong teras, dan bypass teras, juga membelokkan sebagian arah aliran air pendingin primer yang keluar dari teras reaktor, sehingga memperpanjang waktu tempuh air pendingin primer yang membawa $\mathrm{N}-16$ dari permukaan teras ke permukaan tangki, dan akhirnya mengurangi konsentrasi $\mathrm{N}-16$ di permukaan tangki.

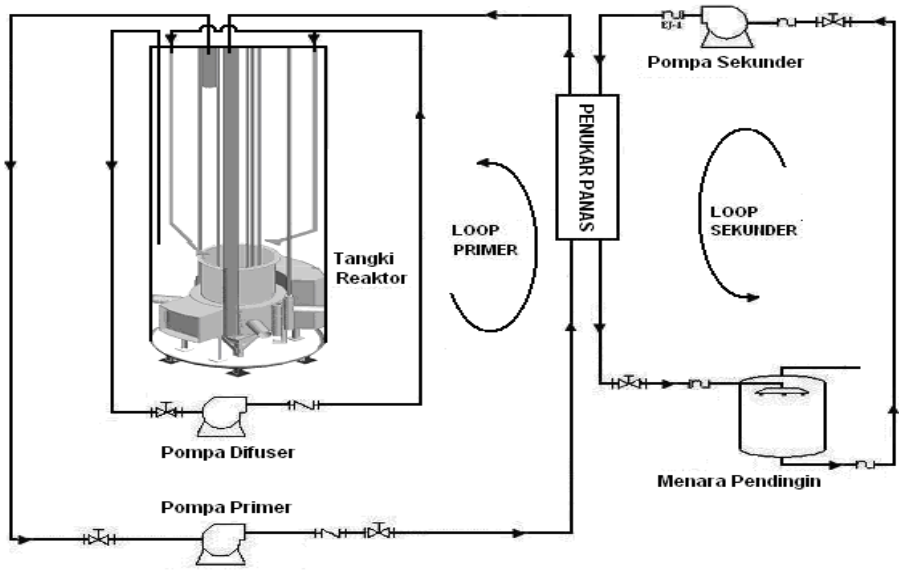

Gambar 1. Diagram sistem reaktor riset yang ditinjau

Proses termohidrolik pada reaktor ini dimulai dengan perpindahan panas hasil fisi dari elemen bahan bakar ke air pendingin primer di dalam teras reaktor secara konveksi alamiah. Panas yang pindah ke air pendingin primer dibawa ke penukar panas melalui sistem pendingin primer untuk dipindahkan ke air pendingin sekunder. Panas yang pindah ke air pendingin sekunder dibawa ke menara pendingin untuk dibuang ke lingkungan.

\section{Deskripsi Program RELAP5/MOD 3.2}

Program komputer RELAP5/MOD3.2 yang merupakan hasil pengembangan beberapa generasi dari paket program komputer RELAP (Reactor Excursion and Leak Analysis Program) (3). Prinsip kerja program komputer RELAP5/ MOD3.2 adalah menggunakan model hidrodinamika dua zat cair (two fluid model) yang bekerja dalam 5 (lima) persamaan dasar yaitu 2 (dua) persamaan kontinuitas massa (untuk uap dan air), 2 (dua) persamaan momentum (untuk uap dan air) dan 1 (satu) persamaan energi total. Pada model ini hanya dibutuhkan dua persamaan konstitutif pada batas uap dan air, yaitu persamaan gesekan (interphase drag) dan persamaan pertukaran massa (interphase mass exchange). Variabel dasar yang digunakan program komputer RELAP5/MOD3.2 adalah kerapatan fasa uap dan cair $(\rho)$, kualitas uap $(\chi)$, energi dalam fasa campuran $(U)$ dan kecepatan alir fasa uap dan fasa cair masing-masing adalah $v_{v}$ dan $v_{1}$. Operasi dasar matematika yang digunakan untuk perhitungan numerik adalah penjumlahan dan pengurangan dari masing-masing persamaan fasa cair dan fasa uap. Perhitungan yang dilakukan pada RELAP5/MOD 3.2 adalah memodelkan sistem hidrodinamika dengan model satu dimensi, transien, dengan aliran dua fasa air-uap yang dapat mengandung gas lain yang tak terkondensasi.

Sistem hidrodinamik yang ditinjau RELAP5/MOD3.2 dimodelkan dalam bentuk nodalisasi komponenkomponen yang menyimulasikan sistem secara keseluruhan. Nodalisasi tersebut antara lain berupa komponen volume, pompa, katup, pipa, struktur pelepasan maupun penyerapan energi kalor, kinetika reaktor, pemanas elektris, pompa jet, turbin, separator, akumulator dan komponen sistem kontrol. Komponen ini berisi data-data 
Jurnal Iptek Nuklir Ganendra

Ganendra Journal of Nuclear Science and Technology

Vol. 16 No. 2 Juli 2013: 97-107

fisis komponen sebenarnya, yaitu geometri dan data fluida. Komponen-komponen terdiri dari satu atau lebih volume yang dihubungkan dengan penghubung (junction) yang berisi data aliran fluida.

\section{Asumsi dan Kondisi Batas}

Teras reaktor riset yang ditinjau memiliki 107 bahan bakar tipe silinder. Distribusi daya yang dibangkitkan setiap bahan bakar agar reaktor beroperasi dengan daya $1 \mathrm{MW}$ dinyatakan pada Tabel 1, dan diasumsikan daya terdistribusi merata pada setiap bahan bakar. Suhu saturasi di teras reaktor $112,4^{\circ} \mathrm{C}$. Suhu air pendingin primer masuk tangki reaktor $32{ }^{\circ} \mathrm{C}$, laju aliran air pendingin primer masuk tangki reaktor $50,21 \mathrm{~kg} / \mathrm{s}$. Suhu air pendingin masuk ke sisi sekunder $29^{\circ} \mathrm{C}$, laju aliran air pendingin sekunder $75,30 \mathrm{~kg} / \mathrm{s}$, laju aliran pada difuser $3,73 \mathrm{~kg} / \mathrm{s}$. Reaktor mengalami kebocoran setelah 2500 detik beroperasi pada daya $1 \mathrm{MW}$, luas penampang kebocoran di beam tube, pipa cold leg. dan pipa hot leg sama dengan luas penampang pipa primer $0,0182 \mathrm{~m}^{2}$. Sistem scram yang digunakan adalah reaktor mengalami scram pada saat level air tangki turun $0,5 \mathrm{~m}$.

Tabel 1. Distribusi daya pada setiap bahan bakar dengan daya total $1 \mathrm{MW}$

\begin{tabular}{|c|c|c|c|c|c|c|c|c|c|}
\hline Fuel & $\begin{array}{c}\text { Power } \\
\text { (kW) }\end{array}$ & Fuel & $\begin{array}{c}\text { Power } \\
\text { (kW) }\end{array}$ & Fuel & $\begin{array}{l}\text { Power } \\
\text { (kW) }\end{array}$ & Fuel & $\begin{array}{l}\text { Power } \\
\text { (kW) }\end{array}$ & Fuel & $\begin{array}{l}\text { Power } \\
(\mathrm{kW})\end{array}$ \\
\hline$A$ & 0 & $\mathrm{~B} 1$ & 16,77 & B2 & 15,85 & B3 & 0 & B4 & 16,45 \\
\hline B5 & 16,60 & $\mathrm{~B} 6$ & 16,50 & C1 & 15,23 & $\mathrm{C} 2$ & 15,83 & $\mathrm{C} 3$ & 15,16 \\
\hline $\mathrm{C} 4$ & 16,87 & $\mathrm{C} 5$ & 15,96 & C6 & 16,27 & C7 & 15,07 & $\mathrm{C} 8$ & 15,72 \\
\hline $\mathrm{C9}$ & 16,52 & C10 & 15,76 & C11 & 15,47 & C12 & 15,64 & D1 & 16,31 \\
\hline D2 & 9,85 & D3 & 14,36 & D4 & 16,73 & D6 & 7,79 & D6 & 14,25 \\
\hline D7 & 16,65 & D8 & 13,70 & D9 & 7,61 & D10 & 16,82 & D11 & 14,27 \\
\hline D12 & 14,79 & D13 & 11,84 & D14 & 13,73 & D15 & 13,88 & D16 & 8,10 \\
\hline D17 & 14,14 & D18 & 13,65 & $\mathrm{E} 1$ & 7,31 & E2 & 9,65 & E3 & 10,19 \\
\hline E4 & 9,31 & $\mathrm{E} 5$ & 7,40 & E6 & 9,39 & E7 & 10,31 & E8 & 0 \\
\hline E9 & 8,66 & E10 & 9,35 & E11 & 10,23 & E12 & 9,79 & E13 & 7,54 \\
\hline E14 & 9,83 & E15 & 0 & E16 & 12,79 & E17 & 7,47 & E18 & 9,51 \\
\hline E19 & 14,76 & E20 & 9,31 & E21 & 7,74 & E22 & 8,56 & E28 & 0 \\
\hline E24 & 9,36 & $\mathrm{~F} 1$ & 6,30 & $\mathrm{~F} 2$ & 7,18 & F3 & 7,13 & $\mathrm{~F} 4$ & 7,03 \\
\hline F5 & 6,57 & F6 & 6,17 & F7 & 6,48 & F8 & 6,85 & F9 & 7,14 \\
\hline F10 & 6,59 & F11 & 6,24 & F12 & 7,11 & F13 & 7,22 & F14 & 5,80 \\
\hline F15 & 5,36 & F16 & 5,65 & F17 & 5,67 & F16 & 7,37 & F19 & 7,17 \\
\hline F20 & 5,95 & F21 & 5,51 & F22 & 5,51 & F23 & 6,48 & F24 & 5,45 \\
\hline F25 & 5,82 & F26 & 5,23 & F27 & 5,63 & F28 & 7,38 & F29 & 6,53 \\
\hline F30 & 5,56 & G2 & 0 & G3 & 5,31 & G4 & 5,14 & G5 & 5,20 \\
\hline G6 & 0 & G8 & 0 & G9 & 5,52 & G10 & 0 & G11 & 5,23 \\
\hline G12 & 5,00 & G14 & 0 & G15 & 5,42 & G16 & 5,05 & G17 & 5,28 \\
\hline G18 & 4,84 & G20 & 4,27 & G21 & 4,69 & G22 & 4,91 & G23 & 5,70 \\
\hline G24 & 0 & G26 & 4,58 & G27 & 5,08 & G28 & 4,85 & G29 & 5,21 \\
\hline G30 & 0 & G32 & 0 & G33 & 4,44 & G34 & 4,42 & G35 & 4,87 \\
\hline G36 & 0 & - & - & - & - & - & - & - & - \\
\hline
\end{tabular}

\section{Pemodelan Reaktor yang Dikaji}

Banyak kemungkinan model-model pendekatan yang dapat dibuat terhadap nodalisasi reaktor yang ditinjau, diantaranya seperti yang pernah dilakukan para peneliti terdahulu ${ }^{(1,2)}$. Pada prinsipnya penelitian terdahulu memodelkan teras reaktor riset yang ditinjau dalam bentuk tiga kanal yaitu, kanal panas, kanal dingin dan kanal rerata, dan tidak terdapat interaksi antara kanal yang satu dengan kanal lainnya. Aliran pendingin dari pipa primer ke tangki reaktor langsung masuk ke bawah teras, kemudian sebagian menuju teras, dan bagian lainnya menuju bypass teras. Untuk kebocoran pada beamtube dinyatakan sebagai aliran dari setiap kanal keluar tangki reaktor (lingkungan), artinya terdapat aliran air panas langsung dari teras ke lingkungan. Sistem scram yang digunakan adalah reaktor mengalami scram ketika suhu air pendingin primer di kolam pencampuran mencapai $49{ }^{\circ} \mathrm{C}$. Di samping model nodalisasi yang disebutkan di atas, banyak lagi model nodalisasi reaktor riset lain yang telah dilakukan para peneliti lainnya ${ }^{(4,5,6,7)}$. Pada penelitian ini dilakukan terhadap suatu model reaktor riset dengan bentuk nodalisasi yang sangat berbeda dengan model yang sudah ada, dimana model nodalisasi reaktor riset yang ditinjau dinyatakan pada Gambar 2.

Nodalisasi yang dilakukan terhadap teras reaktor dengan 107 bahan bakar dimodelkan dalam 7 kanal yang merepresentasikan 7 daerah berbeda di dalam teras. Kanal 1 merepresentasikan daerah teras yang tidak ditempati bahan bakar, kanal 2 merepresentasikan kanal terpanas di daerah ring B, kanal 3 merepresentasikan kanal terpanas di daerah ring $C$, kanal 4 merepresentasikan kanal terpanas di daerah ring $D$, kanal 5 
merepresentasikan kanal terpanas di daerah ring $\mathrm{E}$, kanal 6 merepresentasikan kanal terpanas di daerah ring $\mathrm{F}$, kanal 7 merepresentasi kanal terpanas di daerah ring G. Interaksi antara kanal yang berdekatan dapat terjadi karena adanya crossflow, dan pada model ini diperhitungan adanya crossflow antara kanal-kanal yang berdekatan.

Model nodalisasi di dalam tangki reaktor mengakomodasi posisi ujung pipa primer masuk ke tangki berada 1,252 $\mathrm{m}$ dari dasar tangki atau sejajar dengan permukaan teras reaktor, sehingga aliran air pendingin dari pipa primer ke tangki reaktor langsung masuk ke bypass teras, kemudian sebagian mengalir menuju bawah teras, dan bagian lainnya menuju bypass cerobong. Sedangkan posisi ujung pipa primer keluar dari tangki berada $0,70 \mathrm{~m}$ dari permukaan tangki. Nodalisasi terhadap sistem difuser berupa pompa, sistem pemipaan, katup-katup, dan nozzle berada di atas cerobong teras reaktor. Sistem difuser ini perlu diperhitungkan, karena mempengaruhi suhu air pendingin primer yang keluar dari teras, cerobong teras, bypass teras, dan kondisi di atas cerobong teras reaktor. 


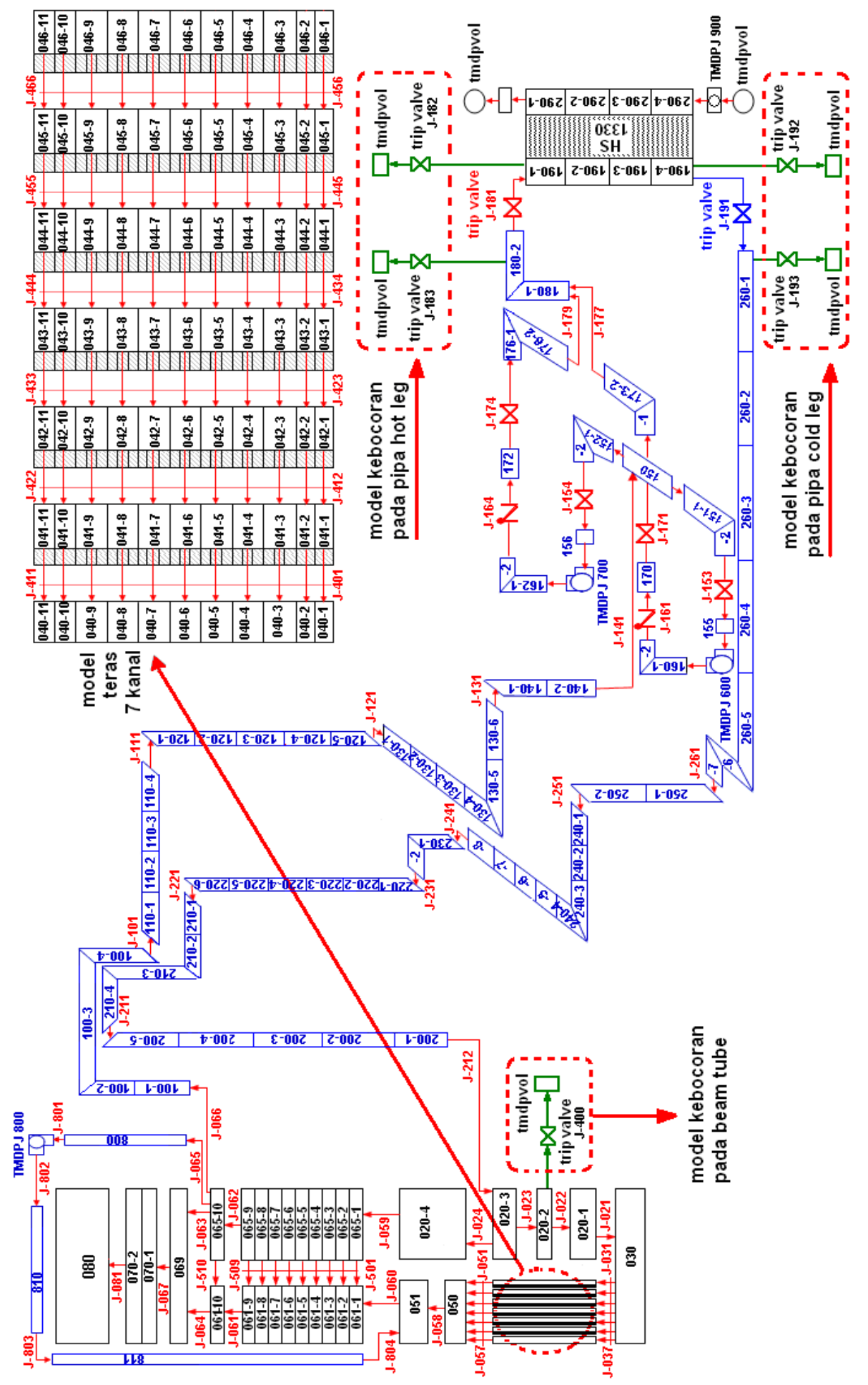

Gambar 2. Nodalisasi RELAP5/Mod 3.2 untuk reaktor riset yang ditinjau

Nodalisasi sistem pemipaan primer dimodelkan dalam bentuk pipe untuk pipa-pipa, junction untuk sambungan, valve untuk katup dan time dependent junction untuk pompa pendingin primer. Nodalisasi sistem pemipaan difuser dimodelkan dalam bentuk pipe untuk pipa-pipa, junction untuk sambungan, valve untuk katup, dan time dependent junction untuk pompa difuser. Nodalisasi sistem pemipaan sekunder dimodelkan sebagai 
suatu untai terbuka dari sebuah sumber air dingin dan penampungan air panas dengan suatu laju alir, tekanan serta suhu masukan yang konstan. Model dalam bentuk pipe untuk pipa-pipa, junction untuk sambungan, valve untuk katup dan time dependent junction untuk pompa. Nodalisasi alat penukar panas mengancu pada model yang telah dibuat untuk the Next Generation Nuclear Plant $(P C H E)^{(7)}$.

Berdasarkan kondisi real posisi beamtube berada $0,959 \mathrm{~m}$ dari dasar tangki atau sejajar dengan posisi setengah teras reaktor. Karena beamtube merupakan pipa penghubung dinding teras dengan luar tangki melalui bypass teras, maka jika terjadi kebocoran pada beamtube akan mengakibatkan aliran air tangki dari bypass teras ke luar tangki reaktor (lingkungan). Dengan demikian kebocoran Beamtube dimodelkan dengan trip valve (J-400) sebagai penghubung bypass teras dengan luar tangki (time dependent volume-tmdpvol). Kebocoran dimulai saat trip valve (J-400) dibuka

Akibat kebocoran pipa cold leg pada sisi primer keluaran penukar panas (260-1), terjadi aliran air tangki (primer) dari sisi keluaran penukar panas (190-4) ke lingkungan (tmdpvol), dan dari pipa cold leg (260-1) ke lingkungan (tmdpvol) akibat efek siphon. Untuk aliran dari sisi keluaran penukar panas (190-4) ke lingkungan (tmdpvol) dimodelkan dengan trip valve (J-192), dan untuk aliran dari pipa cold leg ke lingkungan dimodelkan dengan trip valve (J-193). Kebocoran dimulai saat trip valve (J-192), trip valve (J-193) dibuka, dan katup (J-191) ditutup.

Akibat kebocoran pipa hot leg pada sisi primer masukan penukar panas (180-2) terjadi aliran air tangki (primer) dari pipa hot leg (180-2) ke lingkungan (tmdpvol), dan dari sisi masukan penukar panas (190-1) ke lingkungan (tmdpvol) akibat efek siphon. Untuk aliran dari pipa hot leg ke lingkungan dimodelkan dengan trip valve (J-183), dan aliran dari sisi masukan penukar panas (190-1) ke lingkungan (tmdpvol) dimodelkan dengan trip valve (J-182), Kebocoran dimulai saat trip valve (J-182), trip valve (J-133) dibuka, dan katup (J-181) ditutup, sedangkan sistem scram yang digunakan dalam penelitian ini adalah reaktor mengalami scram ketika level air tangki turun $0,5 \mathrm{~m}$.

\section{Urutan Kejadian}

Kebocoran pada beamtube membuat air pendingin primer dari bypass teras mengalir ke lingkungan melalui beamtube, sehingga level air pendingin primer di permukaan tangki turun. Ketika level air tersebut turun $0,5 \mathrm{~m}$ reaktor padam (scram), tetapi pompa primer, aliran air pendingin primer melalui pompa primer dan beamtube tidak terhenti. Ketika reaktor scram tidak terjadi pembangkitan panas dalam teras, tetapi panas sisa peluruhan masih ada. Fenomena termohidrolik yang terjadi pada kejadian ini dianalisis untuk mengetahui karakteristik aliran air pendingin primer yang terjadi serta apakah suhu kelongsong dan suhu pusat bahan bakar berada pada kondisi aman.

Kebocoran pipa cold leg pada sisi primer keluaran penukar panas mengakibatkan air pendingin primer yang datang dari tangki reaktor ke pipa cold leg melalui pompa primer mengalir ke lingkungan. Kebocoran ini mengakibatkan level air pendingin primer dalam tangki menjadi turun. Ketika level air tersebut turun $0,5 \mathrm{~m}$ reaktor padam (scram), tetapi pompa primer dan aliran air pendingin primer melalui pompa primer tidak terhenti. Ketika reaktor scram tidak terjadi pembangkitan panas dalam teras, tetapi panas sisa peluruhan masih ada. Fenomena termohidrolik yang terjadi pada kejadian ini dianalisis untuk mengetahui karakteristik aliran air pendingin primer yang terjadi serta apakah suhu kelongsong serta suhu pusat bahan bakar berada pada kondisi aman.

Kebocoran pipa hot leg pada sisi primer masukan penukar panas mengakibatkan air pendingin primer yang datang dari tangki reaktor melalui pompa primer ke pipa hot leg tersebut mengalir ke lingkungan. Kebocoran ini mengakibatkan level air pendingin primer dalam tangki menjadi turun. Ketika level air tersebut turun $0,5 \mathrm{~m}$ reaktor padam (scram), tetapi pompa primer dan aliran air pendingin primer melalui pompa primer tidak terhenti. Ketika reaktor scram tidak terjadi pembangkitan panas dalam teras, tetapi panas sisa peluruhan masih ada. Fenomena termohidrolik yang terjadi pada kejadian ini dianalisis untuk mengetahui karakteristik aliran air pendingin primer yang terjadi.

\section{HASIL DAN PEMBAHASAN}

\section{Kebocoran Pada Beamtube}




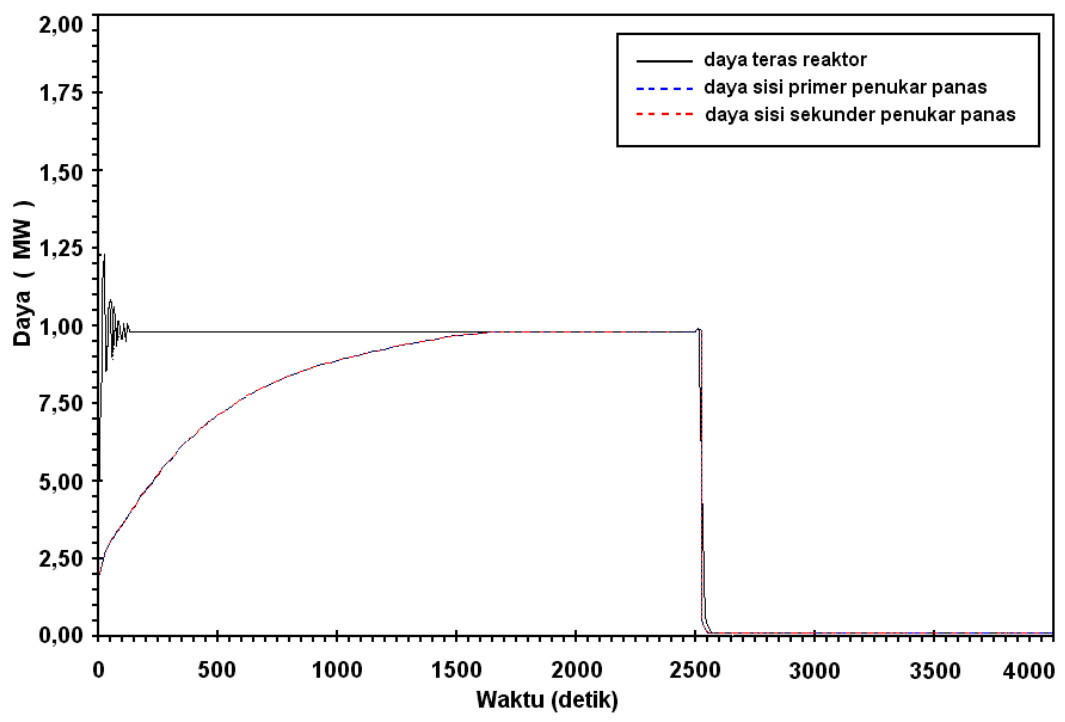

Gambar 3. Daya reaktor pada kondisi tunak dan transien.

Gambar 3 memberikan informasi awal kondisi reaktor stabil pada daya 1 MW mulai tercapai 1650 detik setelah kekritisan. Hal ini ditandai dengan tercapai kondisi daya yang sama antara daya teras reaktor, daya sisi primer dan daya sisi sekunder penukar panas. Pada $t=2500$ detik beamtube bocor dan level air tangki turun, ketika $t=2507,3$ detik level air tangki telah turun 0,5 m sehingga reaktor scram, tidak terjadi pembangkitan panas dalam teras, daya reaktor turun tajam dan hanya meninggalkan panas sisa peluruhan.

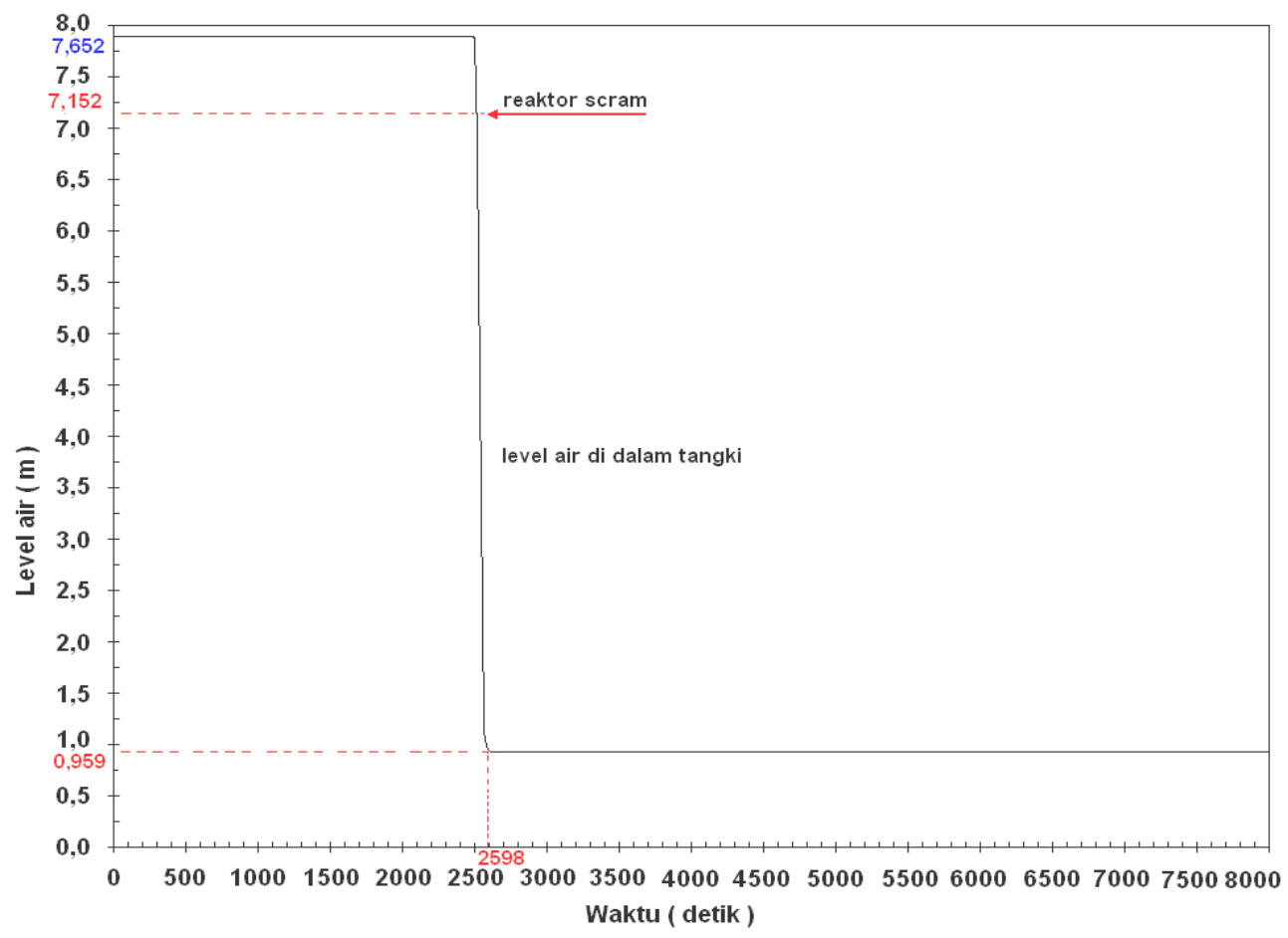

Gambar 4. Level air primer tangki reaktor pada kasus kebocoran beamtube

Gambar 4 memperlihatkan perubahan level air primer tangki reaktor. Saat $t=2500$ detik mulai terjadi kebocoran beamtube, dimana air primer dari teras mengalir ke lingkungan dan menyebabkan level air primer di dalam tangki turun tajam. Pada 7,3 detik setelah beamtube bocor reaktor scram, dipicu oleh level air tangki 
reaktor turun 0,50 m. Penurunan level air tangki berhenti ketika 97,7 detik setelah kebocoran, dimana level air tangki mencapai posisi tinggi setengah teras atau $0,959 \mathrm{~m}$ dari dasar tangki.

Gambar 5 menyatakan bahwa, ketika reaktor kondisi stabil diketahui suhu pusat dan suhu kelongsong bahan bakar pada kanal terpanas, serta suhu pendingin keluar dari kanal terkait berturut-turut adalah $529,35^{\circ} \mathrm{C}$, $98,37^{\circ} \mathrm{C}$, dan $81,27{ }^{\circ} \mathrm{C}$. Ketika reaktor scram dan daya reaktor turun tajam, maka suhu pusat dan suhu kelongsong bahan bakar pada kanal terpanas, serta suhu pendingin keluar dari kanal terkait berturut-turut turun menjadi $79,25^{\circ} \mathrm{C}, 68,10^{\circ} \mathrm{C}$, dan $61,26^{\circ} \mathrm{C}$. Pada $t=2597,7$ detik atau 97,7 detik sejak beamtube bocor level air tangki turun menjadi setengah tinggi teras atau tinggi air tangki $=0,959 \mathrm{~m}$, suhu pusat dan suhu kelongsong bahan bakar pada kanal terpanas, serta suhu pendingin keluar dari kanal terkait berturut-turut naik menjadi 96,25 ${ }^{\circ} \mathrm{C}, 89,63{ }^{\circ} \mathrm{C}$, dan $78,96{ }^{\circ} \mathrm{C}$. Suhu ini mengalami kenaikan karena di dalam teras masih terdapat sisa panas peluruhan, dan air pendingin yang ada tidak mampu mengambil panas sisa tersebut secara maksimal, hingga $t=$ 3031 detik suhu pusat, suhu kelongsong bahan bakar masih mengalami kenaikan, tetapi suhu air pendingin tidak terpantau. Hal ini menunjukkan bahwa mulai $t=3031$ detik air tangki reaktor telah berada di bawah level $0,959 \mathrm{~m}$ dari dasar tangki, karena telah terjadinya penguapan oleh panas sisa peluruhan, hingga $t=5000$ detik suhu pusat dan kelongsong bahan bakar cenderung terus meningkat. Untuk mengatasi supaya suhu pusat dan suhu kelongsong bahan bakar tidak terus naik diperlukan sistem pendinginan teras darurat (SPTD) yang mampu menurunkan suhu bahan bakar.

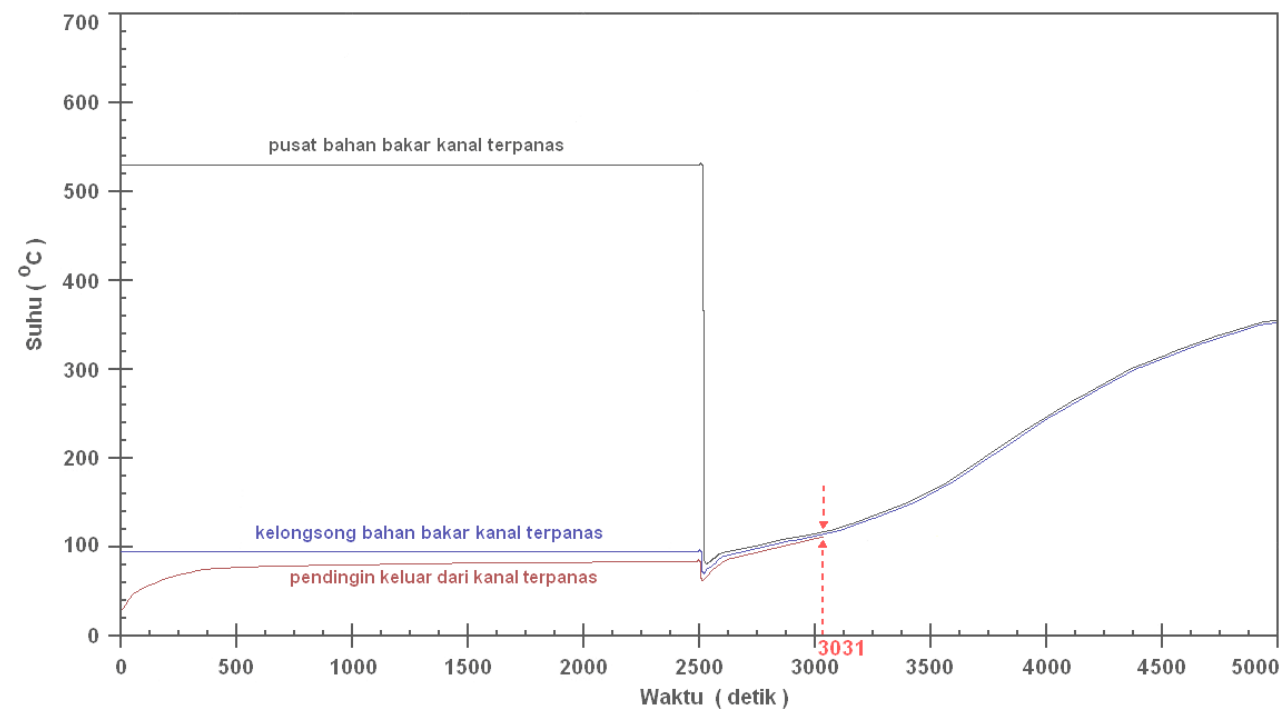

Gambar 5. Suhu pusat dan kelongsong bahan bakar kanal terpanas serta pendingin keluar dari kanal terkait pada kasus kebocoran beamtube

\section{Kebocoran Pada Pipa Cold Leg}

Gambar 6 memperlihatkan perubahan level air tangki reaktor. Ketika $t=2500$ detik terjadi kebocoran pipa cold leg pada sisi primer keluaran penukar panas, sehingga air tangki mengalir ke lingkungan melalui pipa cold leg. Saat 5,1 detik setelah kebocoran level air tangki reaktor turun $0,5 \mathrm{~m}$, sehingga reaktor scram. Pada kasus ini reaktor lebih cepat mencapai scram dibandingkan dengan kasus kebocoran beamtube, karena pada kasus kebocoran pipa cold leg terjadi dua aliran dari tangki reaktor ke lingkungan dengan laju alir total 0,3036 $\mathrm{m}^{3} / \mathrm{s}$, yaitu aliran dari tangki melalui sisi keluaran penukar panas dan aliran dari tangki karena efek siphon melalui pipa cold leg yang merupakan pipa masukan ke tangki reaktor. Sedangkan aliran air tangki ke lingkungan pada kebocoran beamtube adalah aliran jatuh bebas dari tangki melalui pipa beam tube dengan laju alir $0,211 \mathrm{~m}^{3} / \mathrm{s}$.

Ketika 7,1 detik setelah kebocoran level air tangki turun menjadi 0,7 m, dan permukaan air tangki sudah sejajar dengan posisi ujung pipa primer keluaran, sehingga air tangki yang mengalir ke lingkungan hanya melalui ujung pipa primer masukan ke reaktor sebagai efek siphon. Penurunan level air tangki berhenti ketika 76,4 detik setelah kebocoran, level air tangki 1,252 $\mathrm{m}$ dari dasar tangki atau sejajar dengan permukaan teras. 


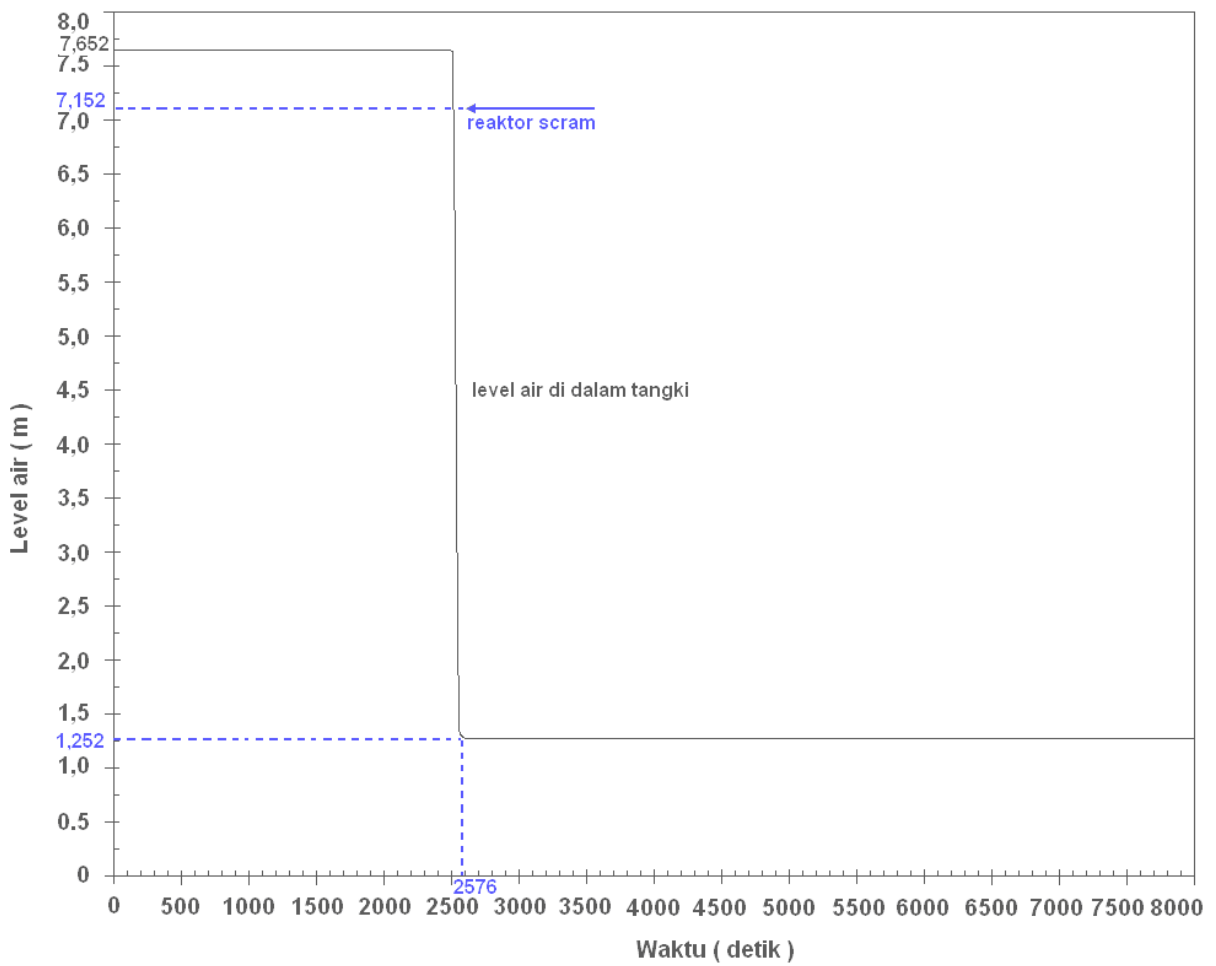

Gambar 6. Level air primer tangki reaktor pada kasus kebocoran pipa cold leg

Gambar 7 menunjukkan pada reaktor kondisi stabil diketahui suhu pusat dan suhu kelongsong bahan bakar pada kanal terpanas, serta suhu pendingin keluar dari kanal terkait berturut-turut adalah $529,35{ }^{\circ} \mathrm{C}, 98,37$ ${ }^{\circ} \mathrm{C}$, dan $81,27^{\circ} \mathrm{C}$. Ketika reaktor scram dan daya reaktor turun tajam, maka suhu pusat dan suhu kelongsong bahan bakar pada kanal terpanas, serta suhu pendingin keluar dari kanal terkait berturut-turut turun menjadi $83,87^{\circ} \mathrm{C}, 70,72{ }^{\circ} \mathrm{C}$, dan $63,96{ }^{\circ} \mathrm{C}$. Ketika level air tangki turun menjadi setinggi teras atau $1,252 \mathrm{~m}$ dari dasar tangki, suhu pusat dan suhu kelongsong bahan bakar pada kanal terpanas, serta suhu pendingin keluar dari kanal terkait berturut-turut naik menjadi $87,12{ }^{\circ} \mathrm{C}, 78,31^{\circ} \mathrm{C}$, dan $69,10^{\circ} \mathrm{C}$, hingga $t=5000$ detik, suhu ini cenderung konstan serta berada jauh di bawah kondisi saturasi, karena sisa air pendingin pimer masih mampu mengambil sisa panas peluruhan di dalam teras

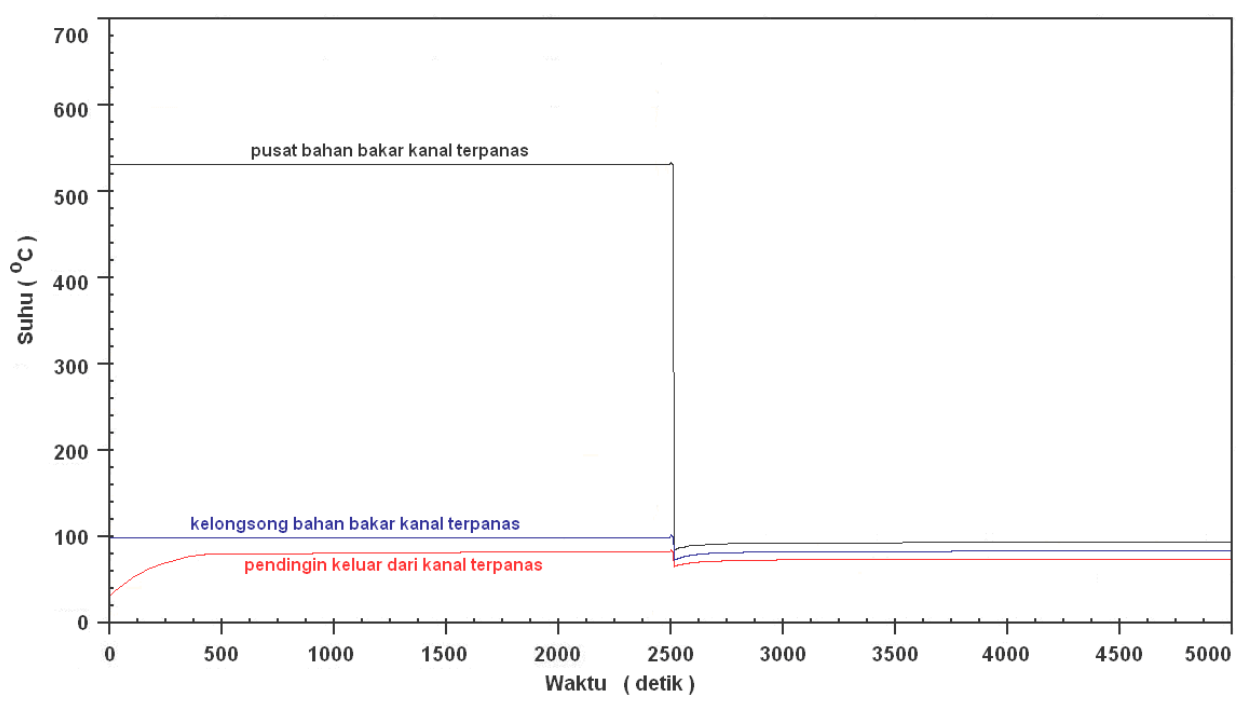


Gambar 7. Suhu pusat dan kelongsong bahan bakar kanal terpanas serta pendingin keluar dari kanal terkait pada kasus kebocoran pipa cold leg

\section{Kebocoran Pada Pipa Hot Leg}

Gambar 8 memperlihatkan perubahan level air tangki reaktor. Ketika $t=2500$ detik terjadi kebocoran pipa hot leg pada sisi primer masukan penukar panas, sehingga air tangki reaktor mengalir ke lingkungan melalui pipa hot leg yang merupakan pipa keluaran dari tangki reaktor, dan aliran dari tangki reaktor ke lingkungan karena efek siphon melalui sisi masukan penukar panas. Saat 6,2 detik setelah kebocoran level air tangki reaktor turun $0,5 \mathrm{~m}$, sehingga reaktor scram.

Ketika 7,9 detik setelah kebocoran level air tangki turun menjadi 0,7 m, dan permukaan air tangki sudah sejajar dengan posisi ujung pipa primer keluaran, sehingga air tangki yang mengalir ke lingkungan hanya melalui ujung pipa primer masukan ke reaktor sebagai efek siphon. Penurunan level air tangki berhenti ketika 78,6 detik setelah kebocoran, level air tangki 1,252 m dari dasar tangki atau sejajar dengan permukaan teras.

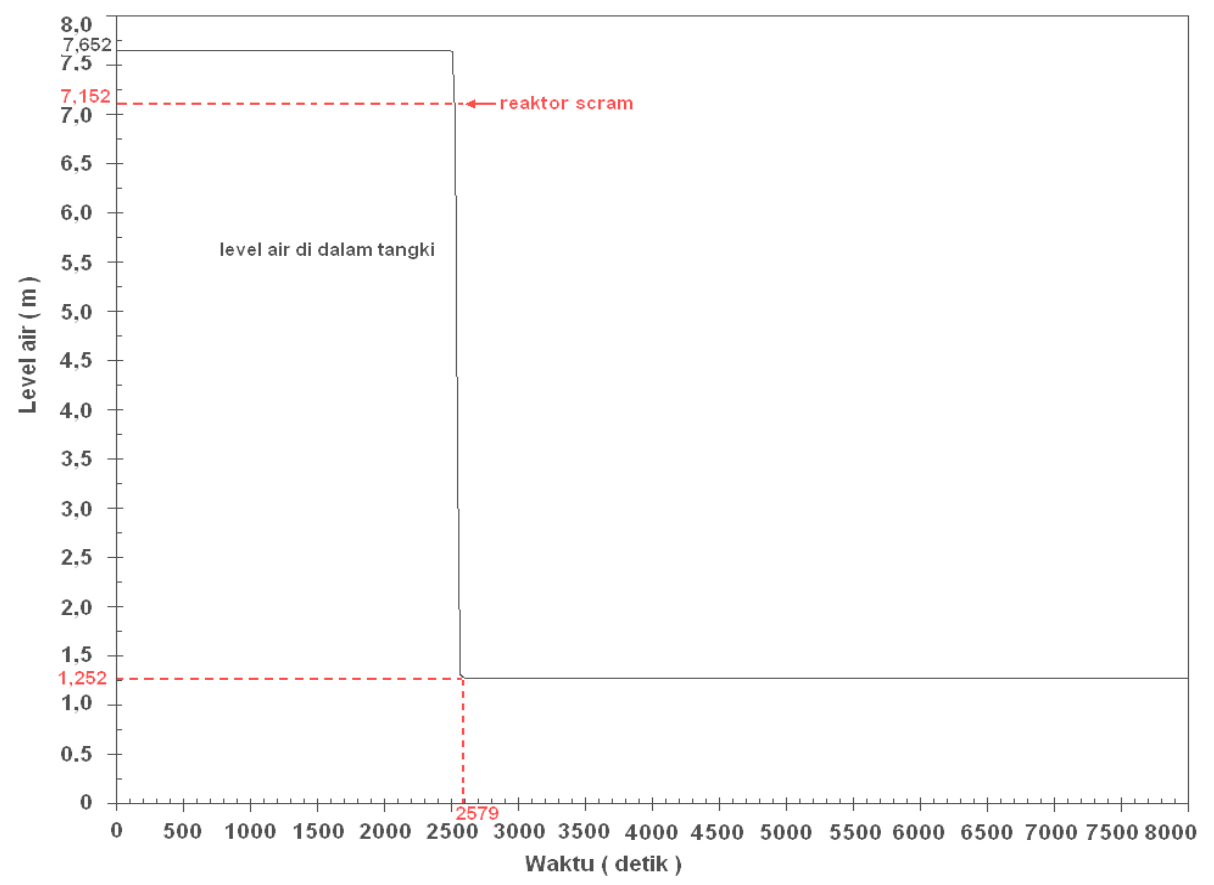

Gambar 8. Perubahan level air tangki reaktor pada kasus kebocoran pipa hot leg

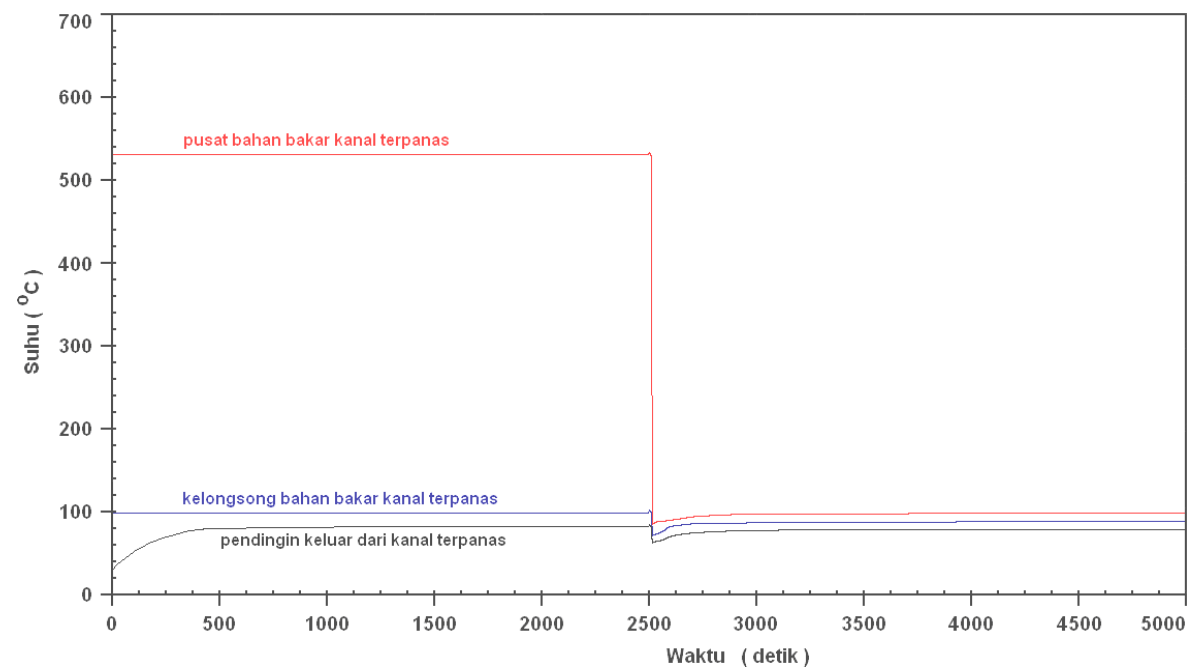


Jurnal Iptek Nuklir Ganendra

Ganendra Journal of Nuclear Science and Technology

Vol. 16 No. 2 Juli 2013: 97-107

Gambar 9. Suhu pusat dan kelongsong bahan bakar kanal terpanas serta pendingin keluar dari kanal terkait pada kasus kebocoran pipa hot leg

Gambar 9 menunjukkan pada reaktor kondisi stabil diketahui suhu pusat dan suhu kelongsong bahan bakar pada kanal terpanas, serta suhu pendingin keluar dari kanal terkait berturut-turut adalah $529,35^{\circ} \mathrm{C}, 98,37$ ${ }^{\circ} \mathrm{C}$, dan $81,27^{\circ} \mathrm{C}$. Ketika reaktor scram dan daya reaktor turun tajam, maka suhu pusat dan suhu kelongsong bahan bakar pada kanal terpanas, serta suhu pendingin keluar dari kanal terkait turun menjadi $84,56{ }^{\circ} \mathrm{C}, 71,48$ ${ }^{\circ} \mathrm{C}$, dan $64,78^{\circ} \mathrm{C}$. Ketika level air tangki turun menjadi setinggi teras atau $1,252 \mathrm{~m}$ dari dasar tangki, suhu pusat dan suhu kelongsong bahan bakar pada kanal terpanas, serta suhu pendingin keluar dari kanal terkait naik menjadi $87,32{ }^{\circ} \mathrm{C}, 78,54{ }^{\circ} \mathrm{C}$, dan $69,43^{\circ} \mathrm{C}$. Hingga $t=5000$ detik, suhu ini cenderung konstan serta berada jauh di bawah kondisi saturasi, karena sisa air pendingin pimer masih mampu mengambil sisa panas peluruhan di dalam teras.

\section{KESIMPULAN}

Suatu model reaktor riset $1 \mathrm{MW}$ berbahan bakar tipe silinder mulai mencapai kondisi stabil 1650 detik setelah kekritisan. Pada kondisi stabil suhu pusat dan suhu kelongsong bahan bakar pada kanal terpanas, serta suhu air pendingin primer keluar dari kanal terkait berturut-turut adalah $529,35^{\circ} \mathrm{C}, 98,37^{\circ} \mathrm{C}, 81,27^{\circ} \mathrm{C}$. Pada 7,3 detik setelah beamtube bocor reaktor scram, karena level air tangki turun $0,5 \mathrm{~m}$. Penurunan air tangki ini terhenti pada level 0,959 m ketika 97,7 detik setelah beamtube bocor. Pada kondisi ini suhu pusat dan suhu kelongsong bahan bakar pada kanal terpanas, serta suhu air pendingin primer keluar dari kanal terkait berturut-turut adalah $96,25{ }^{\circ} \mathrm{C}, 89,63{ }^{\circ} \mathrm{C}, 78,96{ }^{\circ} \mathrm{C}$. Suhu ini cenderung naik karena sisa panas peluruhan, dan air tangki yang tersedia tidak mampu mengambil panas tersebut secara maksimal, sehingga diperlukan sistem pendinginan teras darurat (SPTD) untuk mendinginkannya. Reaktor scram juga terjadi pada 5,1 detik setelah pipa cold leg bocor, dan penurunan air tangki ini terhenti pada level 1,252 m ketika 76,4 detik setelah kebocoran. Pada kondisi ini suhu pusat dan suhu kelongsong bahan bakar pada kanal terpanas, serta suhu air pendingin primer keluar dari kanal terkait berturut-turut adalah $87,12{ }^{\circ} \mathrm{C}, 78,31^{\circ} \mathrm{C}, 69,10^{\circ} \mathrm{C}$, dan air tangki yang tersedia mampu mengambil sisa panas peluruhan secara maksimal. Reaktor scram juga terjadi pada 6,2 detik setelah pipa hot leg bocor, dan penurunan air tangki ini terhenti pada level 1,252 m ketika 78,6 detik setelah kebocoran. Pada kondisi ini suhu pusat dan suhu kelongsong bahan bakar pada kanal terpanas, serta suhu air pendingin primer keluar dari kanal terkait berturut-turut adalah $87,32^{\circ} \mathrm{C}, 78,54^{\circ} \mathrm{C}, 69,43^{\circ} \mathrm{C}$, dan air tangki yang tersedia mampu mengambil sisa panas peluruhan secara maksimal.

\section{DAFTAR PUSTAKA}

ANHAR RA, PURADWI IW, SURIP W, SUSYADI, ISMU H, KISWANTA, dan GIARNO, "Analisis Keselamatan Reaktor TRIGA 2000 Untuk Kejadian LOCA Menggunakan RELAP5/MOD3.2", Prosiding Presentasi Ilmiah Teknologi Keselamatan Nuklir X P2TKN, Serpong (2006) 10-29.

ANHAR R. ANTARIKSAWAN, MD. QUAMRUL. HUDA, TIANCAI LIU, JELENA ZMITKOVA, CHRIS M. ALLISON, JUDITH K, and HOHORST, "Validation of RELAP/SCDAPSIM/MOD3.4 for Research Reactor Applications", 13th International Conference on Nuclear Engineering, ICONE13-50124, Beijing, China, (2005) 1-8.

RELAP5 CODE DEVELOPMENT TEAM, "RELAP5/MOD3.3 Code Manual, Developmental Assessment Problems, NUREG/CR-5535, (3)(2001).

AFSHIN HEDAYAT, HADI DAVILU, and JALIL JAFARI, "Loss of coolant accident analyses on Tehran research reactor by RELAP5/MOD3.2 code", Science Direct, Progress in Nuclear Energy, 49 (2007) 511528.

PATRÍCIA A. L. REIS, ANTONELLA L. COSTA, CLÁUBIA PEREIRA, MARIA A. F. VELOSO, AMIR Z. MESQUITA, and HUMBERTO V. SOARES, "Assessment of a RELAP5 Model for the IPR-R1 TRIGA Research Reactor", International Nuclear Atlantic Conference - INAC 2009, Rio de Janeiro, RJ, Brazil, (2009). 
GEE YANG HAN, and KWI SEOK HA, "Modification and Assessment of RELAP5/MOD 3.2 for HANARO Thermal-Hydraulic Safety Analyses", Journal of the Korean Nuclear Society, 34(5)(2002) 455-467.

PRASHAANTH RAVINDRAN, PIYUSH SABHARWALL, and NOLAN A. ANDERSON, "Modeling a Printed Circuit Heat Exchanger with RELAP5-3D for the Next Generation Nuclear Plant", Idaho National Laboratory,Next Generation Nuclear Plant Project Idaho Falls, Idaho 83415, (2010). 